\title{
Influence of desalinator wastewater for the cultivation of Arthrospira platensis. Fatty acids profile
}

\author{
By Harriet Volkmann ${ }^{1 *}$, Ulisses Imianovsky ${ }^{1}$, Eliana Badiale Furlong ${ }^{2}$, Jorge Luiz Barcelos \\ Oliveira $^{3}$ and Ernani Sebastião Sant'Anna ${ }^{4}$
}

\author{
${ }^{1}$ Post-graduating students of Food Science Program - Federal University of Santa Catarina; \\ ${ }^{2}$ Chemistry Department - Federal University of Rio Grande Foundation; \\ ${ }^{3}$ Department of Rural Engineering; \\ ${ }^{4}$ Food Science Department of Federal University of Santa Catarina. \\ ${ }^{1 *}$ Laboratório de Biotecnologia Alimentar, Departamento de Ciência e Tecnologia de Alimentos, \\ Universidade Federal de Santa Catarina. Rod. Admar Gonzaga 1346, CEP 88034-001. Itacorubi. \\ Florianópolis, Santa Catarina, Brasil. E-mail: harriet.bnu@terra.com.br
}

\section{RESUMEN}

\begin{abstract}
Influencia de agua de desecho de desalación para el cultivo de Arthrospira platensis. Perfil de ácidos grasos.
\end{abstract}

En la región nordeste de Brasil, debido a la elevada salinidad de los acuíferos, existe la necesidad de utilizar procesos de desalación. Sin embargo, estos procesos generan residuos con alta concentración salina, con significativo impacto ambiental. El objetivo de este trabajo fue el cultivo de Arthrospira platensis en tres medios de cultivo diferentes: medio de Paoletti, medio de agua salinizada y medio de agua de desecho obtenida en el proceso de desalación de acuíferos. Las microalgas fueron cultivadas en laboratorio, con condiciones controladas, en fotobiorreactores de $4 \mathrm{~L}$, a $30 \pm 1^{\circ} \mathrm{C}$ y periodos de 12 horas de claridad/oscuridad con iluminación de $140 \mu \mathrm{mol} \cdot \mathrm{m}^{-2} \cdot \mathrm{s}^{-1}$ e inyección constante de aire $\left(0,5 \mathrm{~L} \cdot \mathrm{L}^{-1} \cdot \mathrm{min}^{-1}\right)$. Fue verificado el efecto de los diferentes medios en la concentración celular, productividad, contenido total de lípidos y perfil de ácidos grasos. La mayor concentración celular, así como la productividad máxima fueron encontradas en el medio de agua de desecho de desalación, $4,954( \pm 0,554) \mathrm{g} \cdot \mathrm{L}^{-1}$ y $0,225( \pm 0,042) \mathrm{g} \cdot \mathrm{L}^{-1} \cdot \mathrm{di}^{-1}{ }^{-1}$ respectivamente. En relación a los lípidos totales, se encontraron valores de $4,54 \%$ en el medio de agua de desecho de desalación y 4,69\% en el medio de agua salinizada. En cuanto a los ácidos grasos, se obtuvieron altos índices de ácidos grasos saturados con ambos tratamientos. Con relación al ácido $\gamma$-linolénico, se encontró en un 13,09\% en el medio de agua de desecho de desalación y en un $11,95 \%$ en el medio de agua salinizada.

PALABRAS-CLAVE: Acidos grasos - Agua de desecho de desalación - Arthrospira platenses.

\section{SUMMARY}

Influence of desalinator wastewater for the cultivation of Arthrospira platensis. Fatty acids profile.

The need for a desalination processes in northeastern Brazil is due to the salinity of its water sources. However, these processes produce residues with high saline concentrations and a significant environmental impact. These wastewaters can be used for Arthrospira platensis cultivation. This work aimed to cultivate Arthrospira platensis in three different media: Paoletti Synthetic Medium (PSM), Salinated Water Medium (SWM) and Desalinator Wastewater Medium
(DWWM). Microalgae were cultivated under controlled conditions, in $4 \mathrm{~L}$ photobioreactors, $30 \pm 1^{\circ} \mathrm{C}, 12$ hours of light/dark photoperiod provided by fluorescent lamps at a light intensity of $140 \mu \mathrm{mol} \cdot \mathrm{m}^{-2} \cdot \mathrm{s}^{-1}$ and constant bubbling of air $\left(0.5 \mathrm{~L} \cdot \mathrm{L}^{-1} \cdot \mathrm{min}^{-1}\right)$. The effect of different media on cell concentration, productivity, total content of lipids and fatty acids profile was verified. Higher cell concentration, as well as higher productivity was observed in DWWM: $4.954( \pm 0.554)$ $\mathrm{g} \cdot \mathrm{L}^{-1}$ and $0.225( \pm 0.042) \mathrm{g} \cdot \mathrm{L}^{-1} \cdot \mathrm{day}^{-1}$, respectively. Concerning total lipids, the contents of $4.54 \%$ and $4.69 \%$ were observed in DWWM and SWM, respectively. High levels of saturated fatty acids were observed in both treatments. Concerning $\gamma$-linolenic acid, the contents of $13.09 \%$ (DWWM) and $11.95 \%$ (SWM) were found

KEY-WORDS: Arthrospira platensis - Desalinator wastewater - Fatty acids.

\section{INTRODUCTION}

Large semi-arid areas of northeastern Brazil have serious problems with low pluviometric precipitations and seasonal droughts, besides a frequent occurrence of high levels of saline in its water sources. This problem can be minimized through the captation of groundwater and subsequent desalinization by reverse osmosis. However, the back-washing of membranes produces a highly salinated wastewater with a problematic destination. The present work aims to use this wastewater for composing a medium for Arthrospira platensis cultivation. The production of food and other compounds of interest from microalgae in non conventional systems present several advantages once it allows high levels of production, operating in controlled conditions and low levels of contamination. Arthrospira platensis is produced worldwide for obtaining proteins, carotenoids, vitamins, minerals and PUFAs (Polyunsaturated Fatty Acids), mainly $\gamma$-linolenic acid (Quoc and Dubacq, 1997; Xue et al., 2002; Hongsthong et al., 2003), being the major known source of vitamin B12 (Estrada et al., 2001; Duarte Filho et al., 2002). It presents compounds of 
pharmaceutical interest, having immuno-promoting effects, such as enhancing macrophage functions besides in vitro and in vivo antioxidant activity (Xue et al., 2002). Moreover, it is $85-95 \%$ assimilated by the organism, due to the lack of cellulose in its cell wall (Babadzhanov et al., 2004). Therapeutical significance of $\omega-3$ e $\omega-6$ PUFAs has been recently suggested through clinical and epidemiological investigations (Medina et al., 1998; Renaud et al., 2002; Kroes et al., 2003; Wen and Chen, 2003). Studies, mainly with $\gamma$-linolenic acid, suggest effects such as reduction in blood cholesterol, protection against some cancers, enhancement of the immune system, reduction of hyper lipidemia and obesity and partial inhibition of HIV-1 replication (Jiménez et al., 2003). These findings led to a great interest in the commercial development of a process for the production and extraction of these lipids. PUFAs can be obtained from animal and plant sources, being fish oil its main source. However, fish oils presents a production lower than the required demand, besides its unpleasant odor, contamination with heavy metals, presence of cholesterol, variable production and a complex fatty acid profile (Medina et al., 1998; Renaud et al., 2002; Kroes et al., 2003; Wen and Chen, 2003). On the other hand, PUFAs extracted from microalgae and other microorganisms lack these disadvantages and a simpler fatty acid composition facilitates purification (Medina et al., 1998; Zittelli et al., 1999; Wen and Chen, 2003).

Nevertheless, the PUFA content of algae depends not only on the species, but also on factors related to culture conditions (Volkman et al., 1989; Medina et al., 1998). Knowing that, the objective of this work was to evaluate the lipid and fatty acid contents of Arthrospira platensis grown in different media.

\section{MATERIAL AND METHODS}

\subsection{Microorganism and cultivation conditions}

The Arthrospira platensis strain used in this work was given by the Laboratory of Biochemistry of Chemistry Department from the Federal University of Rio Grande Foundation - FURG/RS. It was kept in a Paoletti Synthetic Medium according to Ferraz et al. (1985), with modifications (Table 1).

\subsection{Culture Media}

Three different media were prepared for cultivation. Paoletti Synthetic Medium (PSM) was used as control medium. Salinated Water Medium (SWM), the second medium, was produced by adding $1.0 \mathrm{~g} \cdot \mathrm{L}^{-1}$ of $\mathrm{NaCl}$ to PSM and the third medium Desalinator Wasterwater Medium (DWWM) was produced by dissolving $50 \%$ of all components of PSM in the desalinization wastewater. This medium was produced as follows: after solubilization of the components in the wastewater, it was
Table 1

Composition of Paoletti Synthetic Medium.

\begin{tabular}{|c|c|c|}
\hline Component & & $\begin{array}{c}\text { Concentration } \\
\left(g \cdot L^{-1}\right)\end{array}$ \\
\hline $\begin{array}{l}\mathrm{NaCl} \\
\mathrm{Na}_{2} \mathrm{SO}_{4} \\
\mathrm{~K}_{2} \mathrm{HPO}_{4} \\
\mathrm{Na}_{2} \mathrm{CO}_{3} \\
\mathrm{NaHCO}_{3} \\
\mathrm{CaCl}_{2} \cdot 2 \mathrm{H}_{2} \mathrm{O} \\
\mathrm{KNO}_{3} \\
\mathrm{MgSO}_{4} \cdot 7 \mathrm{H}_{2} \mathrm{O}\end{array}$ & & $\begin{array}{c}0.92 \\
1.88 \\
0.50 \\
8.89 \\
15.15 \\
0.05 \\
2.57 \\
0.25\end{array}$ \\
\hline $\begin{array}{l}\text { Fe-EDTA sol. }\left(\mathrm{g} \cdot \mathrm{L}^{-1}\right) \text { : } \\
\text { EDTA-Na } \\
\text { FeSO }_{4} \cdot 7 \mathrm{H}_{2} \mathrm{O}\end{array}$ & $\begin{array}{l}29.8 \\
24.9 \\
\end{array}$ & $1.0 \mathrm{~mL}$ \\
\hline $\begin{array}{l}\text { Micronutrients sol. }\left(\mathrm{g} \cdot \mathrm{L}^{-1}\right) \text { : } \\
\mathrm{H}_{3} \mathrm{BO}_{3} \\
\mathrm{MnSO}_{4} \cdot \mathrm{H}_{2} \mathrm{O} \\
\mathrm{ZnSO}_{4} \cdot 7 \mathrm{H}_{2} \mathrm{O} \\
\mathrm{NaMoO}_{4} \cdot 2 \mathrm{H}_{2} \mathrm{O} \\
\mathrm{CuSO}_{4} \cdot 5 \mathrm{H}_{2} \mathrm{O} \\
\mathrm{CoCl}_{2} \cdot 6 \mathrm{H}_{2} \mathrm{O}\end{array}$ & $\begin{array}{r}2.86 \\
1.54 \\
0.22 \\
0.39 \\
0.079 \\
0.038\end{array}$ & $1.0 \mathrm{~mL}$ \\
\hline
\end{tabular}

centrifuged at $4,000 \mathrm{rpm}$ for $15 \mathrm{~min}$ and the precipitate was discarded. Desalinator wastewater was given by Reference Laboratory in Desalination, Campina Grande/PB, Brazil, and its composition is presented in Table 2, which was determined according to United States Environmental Protection Agency methods.

The $\mathrm{pH}$ of the media was adjusted to $9.4 \pm 0.2$, with $3.0 \mathrm{M} \mathrm{KOH}$ solution using a potentiometer (Quimis, Q400A).

\subsection{Inoculum preparation}

Inocula of $A$. platensis were prepared for three media in $500 \mathrm{~mL}$ Erlenmeyer flasks. Microalgae were cultivated in $4 \mathrm{~L}$ photobiorreactors (working volume), with a photoperiod of 12 hours light/dark provided by fluorescent lamps (Philips, 20W) at a light intensity of $140 \mu \mathrm{mol} \cdot \mathrm{m}^{-2} \cdot \mathrm{s}^{-1}$ and constant temperature of $30 \pm 1^{\circ} \mathrm{C}$ (climate controlled room). Experiments were initiated with $10 \%(\mathrm{v} / \mathrm{v})$ of

Table 2

Composition of desalinator wastewater.

\begin{tabular}{lc}
\hline \multicolumn{1}{c}{ Component } & $\begin{array}{c}\text { Desalinator wastewater } \\
\left(\mathbf{m g} \cdot \mathbf{L}^{-1} \mathbf{)}\right.\end{array}$ \\
\hline Bicarbonate & 0.00 \\
Calcium & 585.00 \\
Carbonates & 38.1 \\
Chloride & 4340.04 \\
Phosphate & $<0.05$ \\
Magnesium & 433.00 \\
Nitrate & 779.27 \\
Potassium & 101.50 \\
Sodium & 1245.00 \\
Sulfate & 919.65 \\
\hline
\end{tabular}


inoculum. Media agitation was carried out by a constant bubbling of air $\left(0.5 \mathrm{~L} \cdot \mathrm{L}^{-1} \cdot \mathrm{min}^{-1}\right)$.

\subsection{Evaluation of growth}

The cell growth was measured each 72 hours by absorbance readings at $560 \mathrm{~nm}$ in spectrophotometer (Hitachii, U-1800), according to these equations: $y=-0,4404 x^{2}+2,3763 x-0,0438$ (PSM), $y=0,2811 x^{2}+1,925 x-0,0128$ (SWM) and $y=0,6135 x^{2}+1,1365 x-0,0013$ (DWWM). The equations were elaborated from the correlation of absorbance readings and dry weight taken on the $15^{\text {th }}$ day of a previous experiment under the same conditions. These data were subjected to Polynomial Regression Analysis using Statistica ${ }^{\circledR}$ 6.0 software.

The experiment ended with the decreasing of cell growth. At the end of cultivation, biomass was filtered $(0.45 \mu \mathrm{m}$ cellulose acetate filter), lyophylized (Terroni, LT 1000/8) and stored at $-20^{\circ} \mathrm{C}$. Specific growth rate and productivity were also determined.

\section{5. $\mathrm{pH}$ determination}

The $\mathrm{pH}$ of the growth media was measured at each 72 hours using a potentiometer.

\subsection{Total lipid content and fatty acid profile}

Total lipid content and fatty acid profile were determined only for SWM and DWWM. Lipids were extracted in chloroform:metanol (2:1) according to Folch et al. (1957) and quantified by gravimetry.

After lipid quantification, samples were esterified with boron trifluoride $(1: 10)$ as derivatizing agent according to Metcalfe et al. (1966). The methyl esters from fatty acids were identified on the basis of retention times corresponding to standards (Sigma Chemical Company). Identification was confirmed with Ackerman diagram. Quantification was performed by normalization of peak areas followed by estimation of percentages of each fatty acid in samples.

Gas chromatography of methyl esters was performed using a CG Varian Star (model 3400 CX) equipped with a flame ionization detector, using a DB-WAX capillary column $(30 \mathrm{~m} \times 0.25 \mathrm{~mm}$; 0.25 $\mathrm{mm}$ film thickness). The column was temperature programmed under the following conditions: initial temperature, $100^{\circ} \mathrm{C}$; initial isotherm, $3 \mathrm{~min}$; temperature increasing $5^{\circ} \mathrm{C}$ per min up to $180^{\circ} \mathrm{C}$; intermediate isotherm, $1 \mathrm{~min}$, then temperature increasing $1^{\circ} \mathrm{C}$ per minute up to $200^{\circ} \mathrm{C}$; intermediate isotherm, $4 \mathrm{~min}$, then temperature increasing $2^{\circ} \mathrm{C}$ per minute up to $210^{\circ} \mathrm{C}$; intermediate isotherm, 3 min, then temperature increasing $5^{\circ} \mathrm{C}$ per minute up to $230^{\circ} \mathrm{C}$; final isotherm, $12 \mathrm{~min}$; injector and detector temperatures were 250 and $300^{\circ} \mathrm{C}$, respectively. Helium was used as gas carrier (0.5 $\left.\mathrm{mL} \cdot \mathrm{min}^{-1}\right)$.

\subsection{Statistical analysis}

Results of the analyses were submitted to analysis of variance (ANOVA) with confidence level of $95 \% \quad(p<0.05)$ in order to verify significant differences among media. Statistical analyses were carried out using Statistica ${ }^{\circledR} 6.0$ software.

\section{RESULTS AND DISCUSSION}

\subsection{Effect of culture medium in growth}

Maximum cell concentrations (Figure 1) were observed in day 23: $2.587( \pm 0.082) \mathrm{g} \cdot \mathrm{L}^{-1}$ in PSM (control), $3.545( \pm 0.169) \mathrm{g} \cdot \mathrm{L}^{-1}$ in SWM and 4.954 $( \pm 0.554) \mathrm{g} \cdot \mathrm{L}^{-1}$ in DWWM. Values obtained in DWWM and SWM were $91.49 \%$ and $37.03 \%$ higher respectively than those observed in the control. Values of maximum cell concentration observed in PSM are close to those reported by Oliveira et al. (1999) $\left(2.4 \mathrm{~g} \cdot \mathrm{L}^{-1}\right)$, but lower than the values reported by Rafiqul et al. (2005), who used Zarouk medium and reach $2.7 \mathrm{~g} \cdot \mathrm{L}^{-1}$ at day 20 . However, the obtained values were $49 \%$ higher than values reported by Pelizer et al. (2003) (1.3 g. $\mathrm{L}^{-1}$ ), where significant differences were observed between control (PSM) and DWWM $(p<0.01)$. Relating to specific growth rate, obtained data were: 0.393 $( \pm 0.101)$ day $^{-1}$ for PSM, $0.324( \pm 0.049)$ day $^{-1}$ for SWM and $0.244( \pm 0.155)$ day $^{-1}$ for DWWM. Significant differences were not observed among treatments.

Microalgae cultivated in DWWM presented lower productivity in the first days of cultivation, when compared with other treatments. However, it presented higher concentrations from day 10, reaching a maximum of $0.225( \pm 0.042) \mathrm{g} \cdot \mathrm{L}^{-1} \cdot \mathrm{day}^{-1}$ at day 20 (Figure 2). Maximum values found for PSM and SWM were $0.148( \pm 0.019) \mathrm{g} \cdot \mathrm{L}^{-1} \cdot \mathrm{day}^{-1}$

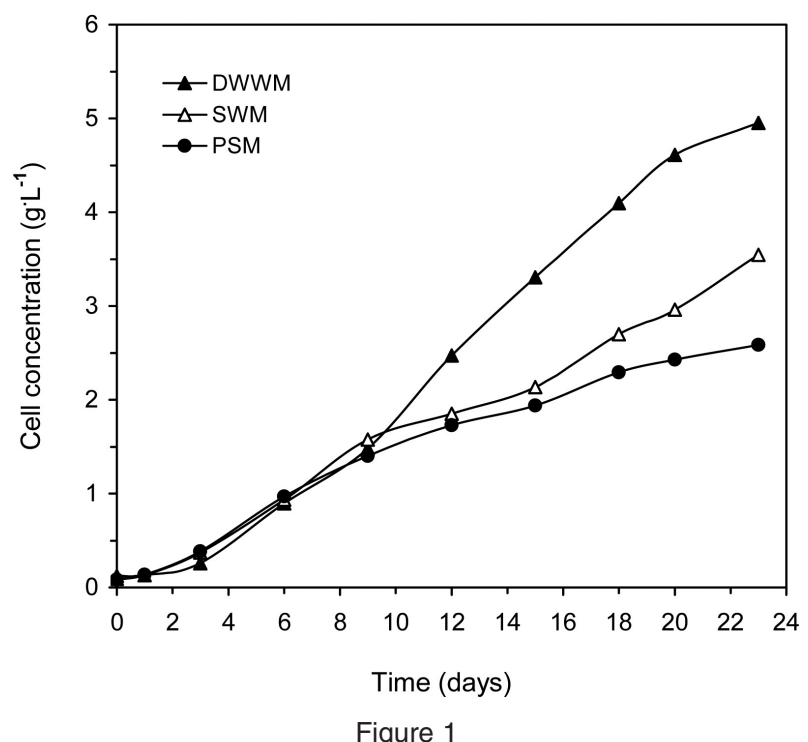

Cell concentration ( $\mathrm{g} \cdot \mathrm{L}^{-1}$ ) of Arthrospira platensis in Paoletti Synthetic Medium (PSM), Salinated Water Medium (SWM) and Desalinator Wastewater Medium (DWWM). 


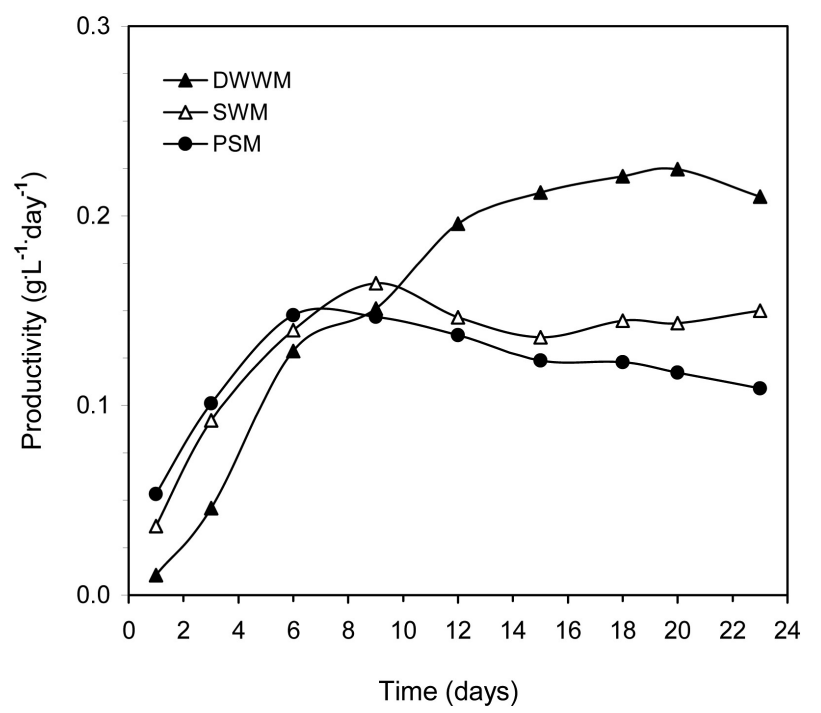

Figure 2

Productivity $\left(\mathrm{g} \cdot \mathrm{L}^{-1} \cdot\right.$ day $^{-1}$ ) of Arthrospira platensis in Paoletti Synthetic Medium (PSM), Salinated Water Medium (SWM) and Desalinator Wastewater Medium (DWWM).

(day 6) and $0.165( \pm 0.020) \mathrm{g} \cdot \mathrm{L}^{-1} \cdot$ day $^{-1}$ (day 9), respectively. Significant differences $(p<0.05)$ were found between PSM and DWWM. The Salinated Water Medium did not present significant differences when compared to other treatments. Microalgae cultivated in DWWM presented higher productivity than those reported $\left(0.175 \mathrm{~g} \cdot \mathrm{L}^{-1} \cdot\right.$ day $\left.^{-1}\right)$ by Oliveira et al. (1999) but lower when compared to Travieso et al. (2001) who found a maximum productivity of $0.40 \mathrm{~g} \cdot \mathrm{L}^{-1} \cdot \mathrm{day}^{-1}$ for $A$. platensis cultivated in BG 11 medium.

$\mathrm{pH}$ values ranged from 9.6 to $10.5,9.6$ to 10.6 and 9.4 to 10.2 for PSM, SWM and DWWM, respectively. This increase in $\mathrm{pH}$ can be correlated to the carbon source consumption. The bicarbonate ions are assimilated by $A$. platensis and subsequently converted into carbon dioxide and carbonate. During the first one is utilization in photosynthesis and excretion of ion carbonate into the medium; an increase in the $\mathrm{pH}$ of the system is generated due to the shift of the bicarbonatecarbonate equilibrium.

\subsection{Effect of culture medium in lipidic content and fatty acids profile}

Total lipid content was $4.54 \%$ and $4.69 \%$ in biomass cultivated in DWWM and SWM respectively, and did not present significant differences $(p>0.05)$. These values are in agreement with those presented by Richmond (1990) but are lower than 6.96\%, 6.38\% and 7.09$8.03 \%$ reported by Oliveira et al. (1999), Xue et al. (2002) and Tokuşoglu and Ünal (2003), respectively.

Fatty acid profiles found in cells grown in DWWM and SWM presented 12 and 24 types of fatty acids, respectively (Table 3 ). Lauric (C12:0) and margaric $(\mathrm{C} 17: 0)$ acids were found in higher proportions in
Table 3

Fatty acid composition (\%) of Arthrospira platensis biomass cultivated in Paoletti Synthetic Medium (PSM), Desalinator Wastewater Medium (DWWM) and Salinated Water Medium (SWM).

\begin{tabular}{|c|c|c|c|}
\hline \multirow{2}{*}{ Fatty Acid } & \multicolumn{3}{|c|}{ Culture Media } \\
\hline & $\mathrm{PSM}^{\mathrm{a}}$ & DWWM & SWM \\
\hline C4:0 & & nd & nd \\
\hline C6:0 & & nd & nd \\
\hline C8:0 & & nd & nd \\
\hline C10:0 & & nd & 0.38 \\
\hline C11:0 & & nd & 9.40 \\
\hline C12:0* & & 36.11 & 15.35 \\
\hline C14:0 & & nd & 0.50 \\
\hline C14:1 & & nd & 1.99 \\
\hline C16:0 & 30.38 & 1.26 & 1.00 \\
\hline C16:1 & 3.39 & nd & 0.98 \\
\hline C17:0* & & 17.29 & 12.63 \\
\hline C17:1 & & 0.80 & 0.54 \\
\hline C18:0* & 2.76 & 0.97 & 12.19 \\
\hline C18:1c & 20.92 & 5.62 & 5.06 \\
\hline C18:1t* & & 8.67 & 0.54 \\
\hline C18:2c & 8.69 & 12.34 & 11.49 \\
\hline C18:2t & & nd & 2.14 \\
\hline 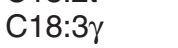 & 13.65 & 13.09 & 11.95 \\
\hline C18:3 & & nd & 0.42 \\
\hline C20:0 & & nd & 2.01 \\
\hline C20:1 & & nd & 0.57 \\
\hline C20:2 & & nd & 0.75 \\
\hline C20:3 & & nd & nd \\
\hline C20:5 & & nd & nd \\
\hline C22:0 & & 1.11 & 0.48 \\
\hline C22:1 & & 0.60 & 0.61 \\
\hline C22:6 & & nd & 6.65 \\
\hline C24:0 & & 0.95 & 0.85 \\
\hline C24:1 & & nd & 0.33 \\
\hline $\mathrm{NI}$ & & 1.87 & 1.17 \\
\hline
\end{tabular}

${ }^{a}$ the data were taken from Oliveira et al. (1999); nd: not detected; NI: total of fatty acids not identified; *statistically significant differences between SWM and DWWM $(p<0,05)$

biomass of both cultivations, the sum of both representing $53.40 \%$ and $27.98 \%$ of total content of fatty acids from DWWM and SWM, respectively. The presence of margaric acid in $A$. platensis was reported by Xue et al. (2002) and Babadzhanov et al. (2004), but in contents of $0.1 \%$ and $1.2 \%$, respectively. Studying forty different strains of $A$. platensis, Mühling et al. (2005) verified that 16 did not present the $\mathrm{C} 17: 0$ fatty acid, indicating variability among them. Statistically significant differences were found between stearic (C18:0) and oleic (C18:1t) fatty acids.

The contents of $\gamma$-linolenic acid were of $13.09 \%$ (DWWM) and 11.95\% (SWM) and are in agreement with Oliveira et al. (1999). However, these values are lower than those reported by Deshnium et al. (2000), who found contents of $20 \%$ when cultivating A. platensis in Zarrouk medium at $35^{\circ} \mathrm{C}$, and Xue et al. (2002) who analyzed dehydrated Arthrospira. On the other hand, Tokuşoglu and Ünal (2003) found values ranging from $3.64 \%$ to $5.52 \%$ when cultivating Arthrospira in Conway medium at $20^{\circ} \mathrm{C}$. 
Docosahexaenoic acid (C22:6) occurred only in the biomass cultivated in SWM. Langdon and Önal (1999) and Tadesse et al. (2003) did not find this fatty acid in Arthrospira platensis biomass. Tokuşoglu and Ünal (2003) found values ranging from $2.30 \%$ to $3.51 \%$ of total lipid content.

A high content of saturated fatty acid was found in DWWM (57.69\%) and in SWM (54.79\%) (Figure 3 ). The saturated and monounsaturated fatty acids contents were higher in desalinator wastewater biomass while polyunsaturated content was higher in salinated water biomass. This can be due to the presence of C18:2t, C18:3 ( $\alpha$-linolenic), C20:2 and C22:6 (DHA) which were found only in the salinated water biomass. Tokuşoglu and Ünal (2003) showed a better distribution of fatty acids in these three groups presenting ranges from $36.40 \%$ to $39.29 \%$ of monounsaturated, $34.09 \%$ to $35.89 \%$ of saturated and $22.30 \%$ to $25.12 \%$ of polyunsaturated. Variations found in fatty acid profiles can be due to different or stressing conditions of cultivation. Walsh et al. (1997) mention an increasing in concentration of saturated fatty acids of microalgae under irradiance stress.

In conclusion, the data obtained in this work indicate that $A$. platensis cultivation in Desalinator Wastewater Medium is possible. It produced almost twice $(91.49 \%)$ as much biomass as the control and presented expected lipid levels for this species. The presence of higher concentrations of saturated fatty acids and lower concentrations of $\gamma$-linolenic can be due to cultivation conditions. However, the use of this microalga in Desalinator Wastewater Medium large scale cultivations must be studied in order to determine its economical viability.

\section{ACKNOWLEDGEMENTS}

The authors would like to express their gratitude to Dr. Kepler Borges França, from Federal University

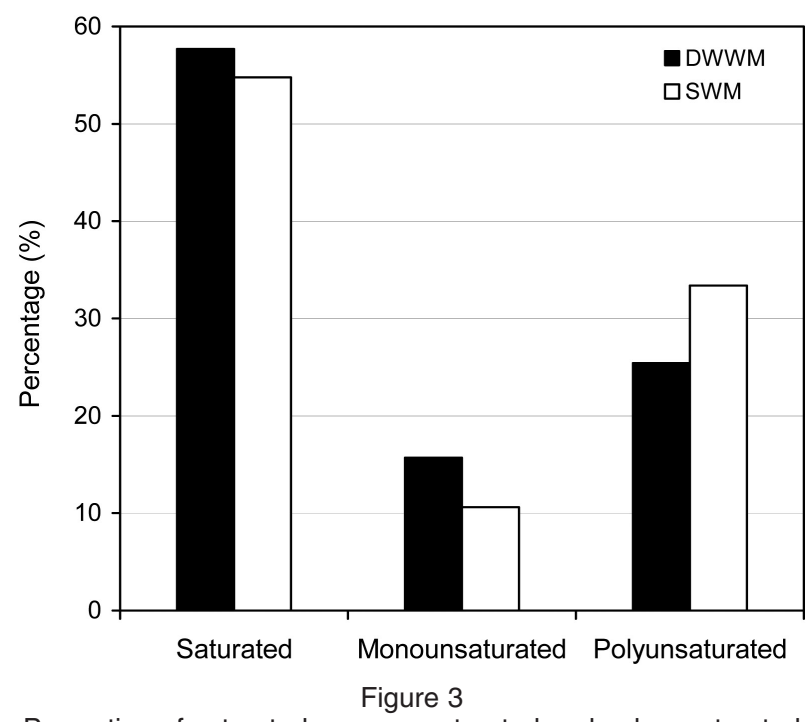

Proportion of saturated, monounsaturated and polyunsaturated fatty acid (\% of total lipids) in Arthrospira platensis biomass cultivated in Salinated Water Medium (SWM) and Desalinator Wastewater Medium (DWWM) of Campina Grande, Brazil, Reference Laboratory in

Desalination by supplying desalinator wastewater.

\section{REFERENCES}

Babadzhanov AS, Abdusamatova N, Yusupova FM, Faizullaeva N, Mezhlumyan LG, Malikova MK. 2004. Chemical composition of Spirulina platensis cultivated in Uzbekistan. Chemistry of Natural Compounds 40, (3) 276-279.

Deshnium P, Paithoonrangsarid K, Suphatrakul A, Meesapyodsuk D, Tanticharoen M, Cheevadhanarak S. 2000. Temperature-independent and -dependent expression of desaturase genes in filamentous cyanobacterium Spirulina platensis strain C1 (Arthrospira sp. PCC 9438). FEMS Microbiology Letters 184, 207-213.

Duarte Filho P, Silva P, Costa JAV. 2002. Estudo do crescimento de duas cepas de Spirulina platensis em diferentes meios de cultura e níveis de agitação. XVIII Congresso Brasileiro de Ciência e Tecnologia de Alimentos, Porto Alegre.

Estrada JEP, Bescós PB, Fresno AMV. 2001. Antioxidant activity of different fractions of Spirulina platensis protean extract. I/ Farmaco 56, 497-500.

Ferraz CAM, Aquarone E, Krauter M. 1985. Efeito da luz e do $\mathrm{pH}$ no crescimento de Spirulina maxima. Revista de Microbiologia 16 (2), 132-137.

Folch J, Less M, Sloane SGH. 1957. A simple method for isolation and purification of lipids from animal tissues. Journal of Biological Chemistry 226, 497-509.

Hongsthong A, Deshnium P, Paithoonrangsarid K, Cheevadhanarak S, Tanticharoen M. 2003. Differential responses of three acyl-lipid desaturases to immediate temperature reduction occurring in two lipid membranes of Spirulina platensis strain C1. Journal Bioscience and Bioengineering 96 (6), 519-524.

Jiménez C, Cossío B, Labella D, Niell FX. 2003. The feasibility of industrial production of Spirulina (Arthrospira) in Southern Spain. Aquaculture 217, 179-190.

Kroes R, Schaefer EJ, Squire RA, Williams GM. 2003. A review of the safety of DHA45-oil. Food and Chemical Toxicology 41, 1433-1446.

Langdon C, Önal E. 1999. Replacement of living microalgae with spray-dried diets for the marine mussel Mytilus galloprovincialis. Aquaculture 180, 283-294.

Medina AR, Grima EM, Gimenez AG, González MJI. 1998. Downstream processing of algal polyunsaturated fatty acids. Biotechnology Advances 16, 517-580.

Metcalfe LD, Schimitz A, Pelke JR. 1966. Rapid preparation of fatty acid esters from lipids for gas liquid cromatography. Analytical Chemistry 38, 514-515.

Mühling M, Belay A, Whitton BA. 2005. Variation in fatty acid composition of Arthrospira (Spirulina) strains. Journal of Applied Phycology 17, 137-146.

Oliveira MACL, Monteiro MPC, Robbs PG, Leite SGF. 1999. Growth and chemical composition of Spirulina maxima and Spirulina platensis biomass at different temperatures. Aquaculture International 7, 261-275.

Pelizer LH, Danesi EDGA Rangel COA, Sassano CEN, Carvalho JCM, Sato S, Moraes IO. 2003. Influence of inoculum age and concentration in Spirulina platensis cultivation. Journal of Food Engineering 56, 371-375. 
Quoc KP, Dubacq JP. 1997. Effect of growth temperature on the biosynthesis of eukaryotic lipid molecular species by the cyanobacterium Spirulina platensis. Biochimica et Biophysica Acta 1346, 237-246.

Rafíqul IM, Jalal KCA, Alam MZ. 2005. Environmental factors for optimisation of Spirulina biomass in laboratory culture. Biotechnology 4 (1), 19-22.

Renaud SM, Thinh LV, Lambrinidis G, Parry DL. 2002. Effect of temperature on growth, chemical composition and fatty acid composition of tropical Australian microalgae grown in batch cultures. Aquaculture 211, 195-214.

Richmond A. 1990. Handbook of microalgal mass culture, CRCPress, Boston.

Tadesse, Z, Boberg, M, Sonesten, L, Ahlgren, G. 2003. Effects of algal diets and temperature on the growth and fatty acid content of the cichlid fish Oreochromis niloticus L. - A laboratory study. Aquatic Ecology 37, 169-182.

Tokuşoglu Ö, Ünal MK. 2003. Biomass nutrient profiles of three microalgae: Spirulina platensis, Chlorella vulgaris, and Isochrisis galbana. Journal of Food Science 68 (4), 1144-1148.

Travieso L, Hall DO, Rao KK, Benítez F, Sánchez E, Borja R. 2001. A helical tubular photobioreactor producing
Spirulina in a semicontinuous mode. International Biodeterioration \& Biodegradation 47, 151-155.

Volkman JK, Jeffrey SW, Nichols PD, Rogers GI, Garland CD. 1989. Fatty acid and lipid composition of 10 species of microalgae used in mariculture. J. Exp. Mar. Biol. Ecol. 128, 219-240.

Walsh K, Jones GJ, Dunstan RH. 1997. Effect of irradiance on fatty acid, carotenoid, total protein composition and growth of Microcystis aeruginosa. Phytochemistry 44 (5), 817-824.

Wen ZY,Chen, F. 2003. Heterotrophic production of eicosapentaenoic acid by microalgae. Biotechnology Advances 21, 273-294.

Xue C, Hu Y, Saito H, Zhang Z, Li Z, Cai Y, Ou C, Lin H, Imbs AB. 2002. Molecular species composition of glycolipids from Sprirulina platensis. Food Chemistry 77, 9-13

Zittelli GC, Lavista F, Bastianini A, Rodolfi L, Vincenzini M, Tredici MR. 1999. Production of eicosapentaenoic acid by Nannochloropsis sp. cultures in outdoor tubular photobioreactors. Journal of Biotechnology 70, 299-312.

Recibido: 18/12/06 Aceptado: 04/09/07 